\title{
Absolute Configuration Reassignment of Natural Products: An Overview of the Last Decade
}

\author{
Andrea N. L. Batista, ${ }^{\oplus a}$ Bianca R. P. Angrisani, ${ }^{a}$ Maria Emanuelle D. Lima, ${ }^{a}$ \\ Stephanie M. P. da Silva, ${ }^{a}$ Vitória H. Schettini, ${ }^{\circledR a}$ Higor A. Chagas, ${ }^{a}$ \\ Fernando M. dos Santos Jr., ${ }^{a}$ João M. Batista Jr. ${ }^{\circledR *, b}$ and Alessandra L. Valverde ${ }^{\circledR *, a}$ \\ ${ }^{a}$ Departamento de Química Orgânica, Instituto de Química, Universidade Federal Fluminense, \\ Outeiro de São João Batista s/n, 24020-141 Niterói-RJ, Brazil \\ ${ }^{b}$ Departamento de Ciência e Tecnologia, Instituto de Ciência e Tecnologia, \\ Universidade Federal de São Paulo, Rua Talim No. 330, 12231-280 São José dos Campos-SP, Brazil
}

\begin{abstract}
The assignment of absolute configuration (AC) is a crucial step in the structural characterization of natural products, especially for those subjected to biological assays. Methods such as X-ray crystallography, stereocontrolled organic synthesis, nuclear magnetic resonance (NMR), and chiroptical spectroscopies are commonly used to determine the AC of chiral natural compounds. Even with these well-established techniques, however, unambiguous stereochemical assignments of natural products remain a challenge, resulting in an increasing number of structural misassignments being reported every year. Herein, we will present the main techniques that have been used in AC reassignments of natural products over the last 10 years, along with some selected examples. Special attention will be paid to the strengths and weaknesses of each approach. With this, we expect to provide the readers with critical information to help them to choose the appropriate methods for correct AC determinations.
\end{abstract}

Keywords: secondary metabolites, stereochemical reassignment, structure revision, misassignment

\section{Introduction}

Natural products and/or natural product structural scaffolds have played a significant role in the drug discovery and development processes over the years due to their wide range of biological activities. ${ }^{1}$ Even today, a large number of new chemical entities of pharmaceutical interest are developed with the help of natural products, since they offer complementary features to synthetic compounds in terms of composition, weight, size, functional groups, and architectural and stereochemical complexity. ${ }^{2}$ Lovering et al. ${ }^{3}$ reported that both intricacy and the presence of chiral centers are correlated with the successful passage of compounds from discovery, through clinical testing, to drugs. Thus, such success of natural products in the drug discovery pipeline has been attributed to the structural complexity of molecules found in living organisms, which have an average of 6.2 chiral centers per molecule when compared to an average of 0.4 chiral centers in molecules found in synthetic combinatorial libraries. ${ }^{4}$

*e-mail: batista.junior@unifesp.br; alessandravalverde@id.uff.br
Although several chiral drugs currently in the market are racemates (equimolar mixture of two enantiomers), many stereoisomers of chiral drugs exhibit marked differences in their pharmacological, toxicological, pharmacokinetics, and metabolism properties. ${ }^{5}$ This is observed because the interaction between a drug molecule and its target is mostly dependent on the three-dimensional environment around them. Plenty of examples of chiral drugs whose enantiomers vary drastically in their properties are reported for commercially available drugs, such as the antidepressant citalopram and the antitubercular agent ethambutol. In the former, the $(+)-(S)$-enantiomer is 100 times more potent than the $(-)-(R)$-stereoisomer; in the latter, the $(S, S)$-enantiomer is active while the $(R, R)$-enantiomer causes optical neuritis that can lead to blindness. ${ }^{6}$ As a result, there currently is a tendency in the pharmaceutical industry to switch from racemates to single enantiomers. ${ }^{7}$

In this context, the structural characterization of chiral compounds, especially those that will have their biological activities evaluated, must include the unambiguous assignment of their absolute configurations (AC). However, 
even today, the configurational assignment of natural products remains a challenge. ${ }^{8}$

The main techniques available to determine $\mathrm{AC}$ are $\mathrm{X}$-ray crystallography, nuclear magnetic resonance (NMR) methods, stereocontrolled organic synthesis, and chiroptical spectroscopy. Each of these methods, however, presents some limitations for natural product molecules. X-ray crystallography, despite providing resolution at atomic level, requires a single well-defined crystal, ${ }^{9}$ which can be difficult to achieve in the case of natural products, especially for terpenes and related molecules. NMR spectroscopy is the main technique used for small molecule structural elucidation, however, as it is normally used in isotropic media, it is intrinsically insensitive to chirality. To that end, it requires the use of chiral auxiliaries, chiral solvents and related methods. ${ }^{10}$ Stereocontrolled organic synthesis is dependent on the correct $\mathrm{AC}$ of both starting materials and products, besides being expensive, laborious, and time-consuming. ${ }^{11}$ Chiroptical methods, which include OR (optical rotation), ORD (optical rotatory dispersion), ECD (electronic circular dichroism), VCD (vibrational circular dichroism), and ROA (Raman optical activity), are naturally sensitive to chirality, yet also have limitations. Flexible molecules can be particularly difficult to analyze due to the presence of multiple conformers in solution which may present opposite optical contributions. ${ }^{12}$ Moreover, for ECD analyses, proper UV/Vis chromophores are required within the molecule. In the case of VCD and ROA, the determination of AC depends mainly on a good correspondence between experimental and theoretical spectra, that results in high computational demands. ${ }^{8}$

As a result, even with the use of these well-established methods, a significant number of errors in the AC determination of natural products still occur. A common practice within the natural product community involves the determination of the AC of natural products based on comparisons of the OR and/or ECD experimental data with those described for analogous molecules. In some cases, spectral analyses based on empirical rules are also carried out. Such approaches, however, are not always applicable since similar molecules, containing the same absolute stereochemistry, have been reported with oppositelysigned OR values, and empirical rules constantly present exceptions. ${ }^{13-15}$

Due to the points raised above and recent advancements in structural characterization techniques, a series of stereochemical reassignments of chiral molecules have been described in the literature. ${ }^{16}$ The present review has surveyed examples of natural products that have had their ACs reassigned over the 2010-2020 period. "Absolute configuration reassignment" or "stereochemical reassignment" associated with "natural products" were used as keywords to perform a search in the available databases (ACS, PubMed, RSC, Science Direct, SciFinder, Scopus, Web of Science, and Wiley databases). In the cases of compounds with multiple chiral centers, the reassignment of the AC commonly leads to (or derives from) revisions of the relative configuration. In this review, we considered as examples only the cases where the cited article mentions stereochemical corrections in absolute sense. Despite trying to address as many cases as possible within the chosen search criteria, this review does not aim to exhaust the literature. Its main goals are to evidence the gradual increase in the number of articles dealing with stereochemical reassignments of natural products over the last decade (Figure 1), describe the main techniques employed in the original incorrect assignments as well as those used for the stereochemical corrections. As computational methods have become a common tool in the structural elucidation process, some general guidelines for the correct prediction of spectral properties will also be provided. By doing this, we want to highlight the importance of the proper choice of either individual or combined methods to determine unequivocally the AC of natural products.

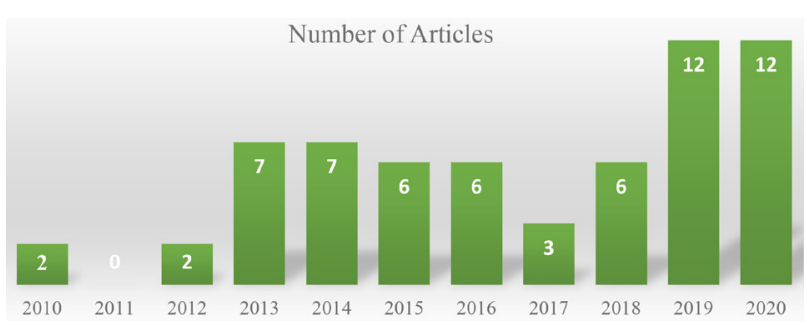

Figure 1. Number of articles dealing with absolute configuration reassignments of natural products over the last decade, according to the search criteria used.

\section{Misassignments of the Absolute Configura- tion of Natural Products}

In this section, we present a list of natural compounds subjected to the revision of AC over the last decade. The results will be presented based on the main method used in the reassignment.

\subsection{Synthesis}

Organic synthesis associated with NMR, X-ray crystallography and/or chiroptical methods has been by far the most widely used approach for the stereochemical reassignment of natural products (Table 1). About 70 percent of the articles surveyed in this review used this methodology. 
Table 1. Absolute configuration reassignment of natural products using synthesis as the main approach (2010-2020)

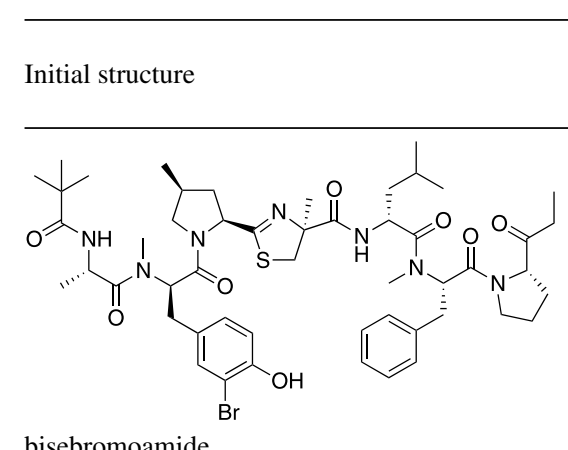

bisebromoamide

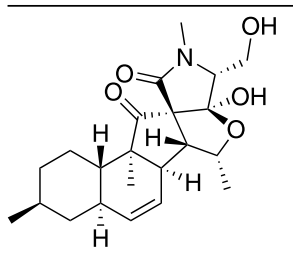

(+)-(1S,3R,4S,5R,6R,7R,11R,12S,15S,16R)-fusarisetin A

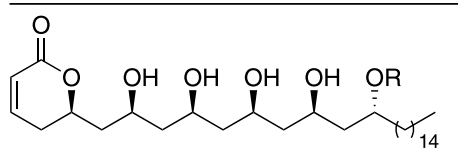

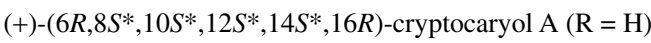
$\left(6 R, 8 S^{*}, 10 S^{*}, 12 S^{*}, 14 S^{*}, 16 R\right)$-cryptocaryol B $(\mathrm{R}=\mathrm{Ac})$<smiles>C#C/C=C\C[C@H]1O[C@@H]([C@H]2C[C@H](O)[C@@H](CC)O2)C[C@H]1O</smiles>

(-)-laurefurenyne A (3Z) (-)-laurefurenyne B $(3 E)$<smiles>C/C(=C/[C@@H](C)[C@@H](O)C1=CC(=O)C=C(NC(=O)[C@H](C)C(=O)C(C)C)C1=O)CC(C)C</smiles><smiles>CC(=O)C[C@@H](C)C(=O)[C@@H](C)C(=O)Nc1cc(O)cc([C@H](O)[C@H](C)/C=C(/C)CC(C)C)c1O</smiles>

(-)-Q-1047H-A-A (-)-Q-1047H-R-A

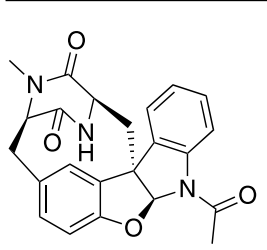

(+)-(2R,10R,11S,19R)-azonazine

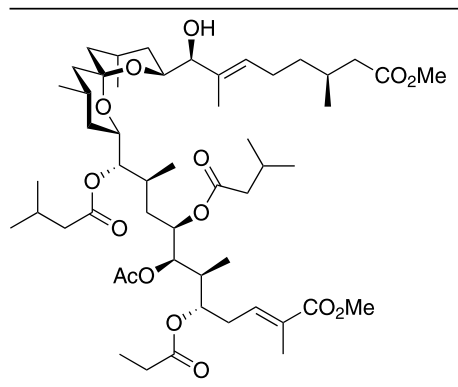

didemnaketal B

Revised structure

Methods used in the reassignment chemical degradation and chiral HPLC ${ }^{17}$ exciton chirality
$\mathrm{CD}^{19}$

exciton chirality
$\mathrm{CD}^{19}$

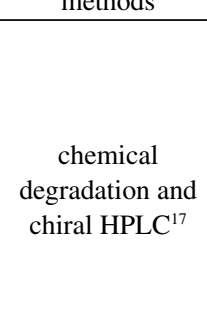


Table 1. Absolute configuration reassignment of natural products using synthesis as the main approach (2010-2020) (cont.)

Initial structure
$\begin{gathered}\text { Initial structure } \\ \text { determination } \\ \text { methods }\end{gathered}$

(+)-fortucine

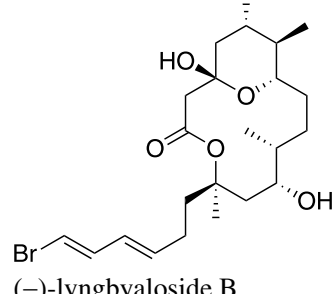

NMR and comparison with analogues $^{33}$

exciton chirality $\mathrm{CD}$ method $^{35}$

comparison of $\mathrm{OR}$ with analogues ${ }^{37}$

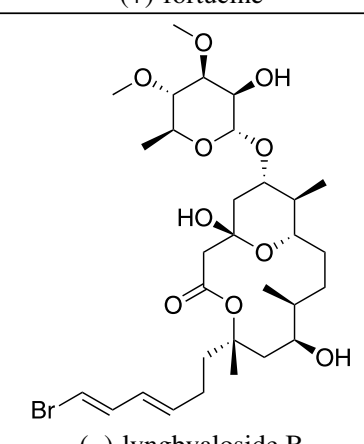

(-)-lyngbyaloside B synthesis and comparison of OR and NMR data ${ }^{34}$<smiles>CO[C@@H]1C(=O)c2c(oc3ccccc23)[C@H](O)[C@@H]1OC</smiles><smiles>CO[C@H]1C(O)c2oc3ccccc3c2C(=O)[C@@H]1OC</smiles>

synthesis and comparison of OR and NMR data ${ }^{36}$

(-)-(2R,3S,4S)-ribisin C<smiles>[2H]OC(=O)O</smiles>

(-)-ribisin $\mathrm{C}$

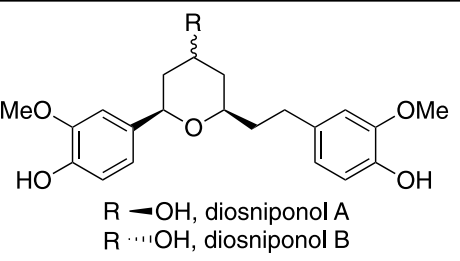

synthesis and comparison of $\mathrm{OR}$ and NMR data ${ }^{38}$

(+)-diosniponol A (+)-diosniponol B

(1S,3R,5S)-diosniponol A

(+)-(1S,3S,5S)-diosniponol A

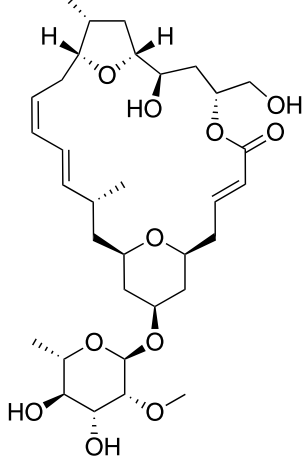

hydrolysis and chiral GC-MS analysis and ROESY data ${ }^{39}$ mandelalide $\mathrm{A}$<smiles>C/C=C(\C)C(=O)O[C@H](/C=C/[C@@H](O)[C@H](C)O)[C@H]1CCC(=O)O1</smiles>

(-)-(1R,2E,4S,5R)-1-[(2R)-5-oxotetrahydrofuran-2-yl]4,5-dihydroxy-hex-2-en-1-yl(2E)-2-methylbut-2-enoate comparison with analogous compound $^{41}$

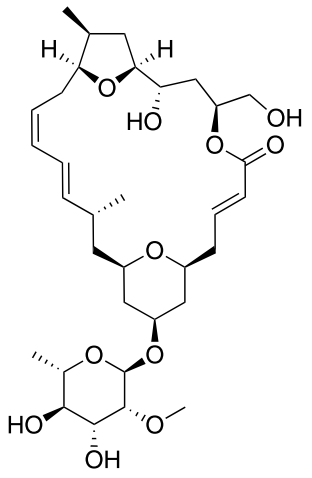

(-)-mandelalide A synthesis and comparison of OR and NMR data ${ }^{40}$<smiles>C/C=C(\C)C(=O)O[C@H](/C=C/C(O)[C@H](C)O)[C@H]1CCC(=O)O1</smiles>

$(-)-(E)-\{(1 R, 4 S, 5 R, E)-4,5$-dihydroxy-

1-[(R)-5-oxotetrahydrofuran-2-yl]hex-2-enyl $\}$ 2-methylbut-2-enoate 
Table 1. Absolute configuration reassignment of natural products using synthesis as the main approach (2010-2020) (cont.)

Initial structure
determination
methods

$$
\text { (n) }
$$

Yaku' amide $\mathrm{A}(\mathrm{R}=\mathrm{H})$

Yaku'amide $\mathrm{B}(\mathrm{R}=\mathrm{Me})$

$$
\text { (1) }
$$

maedamide<smiles>CC(=O)OC(C/C(C)=C/CC/C=C/C(=O)CC1=CC(=O)C(=O)O1)C(C)C</smiles>

(-)-isosarcophytonolide D<smiles>N[C@@H](CN[C@@H](CN[C@H](CC(=O)O)C(=O)O)C(=O)O)C(=O)O</smiles>

(-)-(2" $\left.R, 2^{\prime} R, 2 S\right)$-aspergillomarasmine A

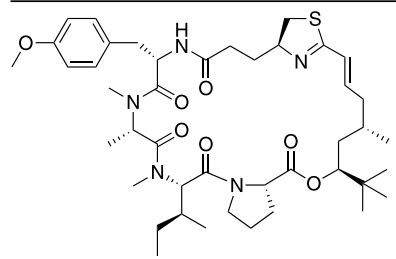

(-)-(30S)-apratoxin E

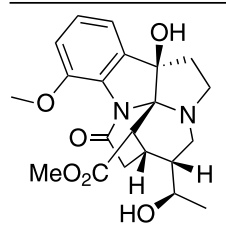

modified Mosher analysis and ECD calculations $^{55}$
Marfey's and dansylation analyses $^{45}$ hydrolysis, chiral HPLC analysis, and modified Mosher analysis $^{47}$
NMR $^{\mathrm{a}} 49$

degradation studies ${ }^{51}$ biosynthetic considerations, hydrolysis and chiral HPLC analysis ${ }^{53}$

$$
\text { (t) }
$$

(+)-maedamide

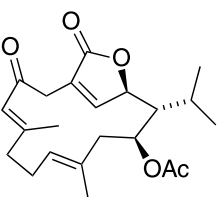

(-)-isosarcophytonolide D<smiles>NC(CN[C@@H](CN[C@H](CC(=O)O)C(=O)O)C(=O)O)C(=O)O</smiles>

(-)-(2" $S, 2$ ' $S, 2 S)$-aspergillomarasmine A

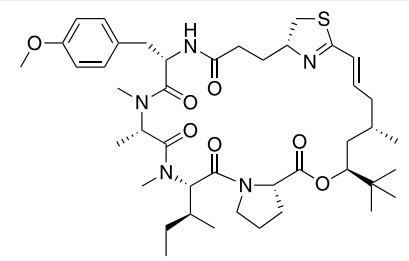

$(-)-(30 R)$-apratoxin E

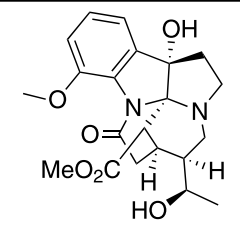

synthesis and comparison of NMR and OR data ${ }^{56}$ 
Table 1. Absolute configuration reassignment of natural products using synthesis as the main approach (2010-2020) (cont.)

\begin{tabular}{cccc}
\hline Initial structure & $\begin{array}{c}\text { Initial structure } \\
\text { determination } \\
\text { methods }\end{array}$ & Revised structure & $\begin{array}{c}\text { Methods used in the } \\
\text { reassignment }\end{array}$ \\
\hline $\mathrm{HO}$ & & $\mathrm{HO}$
\end{tabular}<smiles>CC[C@H](C)/C=C/C1=CC2=C(Cl)C(=O)[C@@]3(C)OC(=O)C(C(=O)[C@H](C)O)=C3[C@@H]2CO1</smiles>

(+)-chaetoviridin A<smiles>CC1OC2(C=Cc3cccc(O)c3CO2)CC2(C=Cc3cccc(O)c3CO2)OC1C</smiles>

(-)-(3S,3' $\left.S, 12 R, 12^{\prime} R\right)$-pestalospirane B<smiles>O=C1NC(=O)/C(=C/C(O)CNC(=O)c2cc(Br)c(Br)[nH]2)N1</smiles>

(-)-(9R)-mukanadin $\mathrm{F}$<smiles>COC(=O)C1=CC2C[C@@H](C)CC[C@H]2[C@@]2(O)[C@@H](O)C[C@@H](C(C)C)C(=O)[C@]12O</smiles>

(+)-sarcophytin<smiles>CC(C)=CC[C@@]1(CC2NC(=O)[C@@H](CC(C)C)OC2=O)CNc2ccccc21</smiles>

(-)-mollenine A $(\mathrm{R}=\mathrm{H})$

$(-)$-mollenine $\mathrm{B}(\mathrm{R}=\mathrm{CHO})$<smiles>CC(=O)C1[C@H]2C[C@@](C)(CO)C[C@H]2[C@@]2(C)CCC12O</smiles>

(+)-repraesentin F

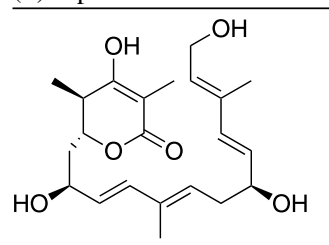

(+)-2,18-seco-lankacidin B

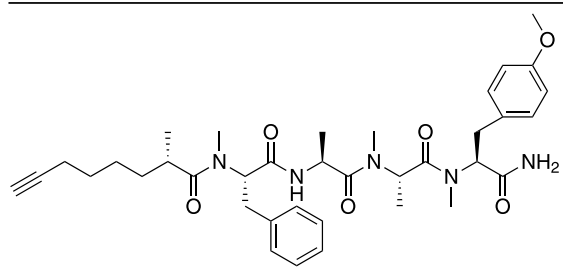

(-)-dragomabin

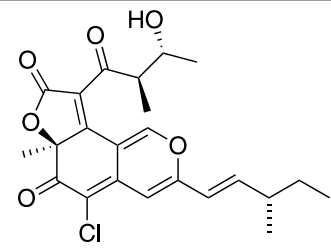

synthesis and comparison of ECD and NMR data ${ }^{58}$

(+)-(7S, $\left.4^{\prime} R, 5^{\prime} R, 11 S\right)$-chaetroviridin-A

ECD calculations ${ }^{59}$<smiles>C[C@H]1C=Cc2cccc(O)c2CO[C@H](C)[C@]2(C=Cc3cccc(O)c3CO2)O1</smiles>

$(-)-\left(3 R, 3^{\prime} R, 12 S, 12^{\prime} S\right)$-pestalospirane $\mathrm{B}$

Mosher analysis $^{61}$<smiles>O=C1NC(=O)/C(=C/[C@@H](O)CNC(=O)c2cc(Br)c(Br)[nH]2)N1</smiles>

(-)-(9S)-mukanadin F synthesis, comparison of ECD, and X-ray crystal data $^{60}$

synthesis, comparison of OR and NMR data ${ }^{62}$ comparison of OR and NMR data ${ }^{64}$
NMR and X-ray crystal data ${ }^{63}$
$\mathrm{OR}^{65}$

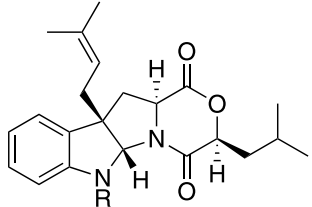

synthesis, analysis of NMR data and ECD calculations ${ }^{66}$

$(-)-(3 S, 6 S, 14 S, 16 S)$-mollenine A $(\mathrm{R}=\mathrm{H})$

$(-)-(3 S, 6 S, 14 S, 16 S)$-mollenine $\mathrm{B}(\mathrm{R}=\mathrm{CHO})$

2D NMR and comparison with analogues $^{6}$

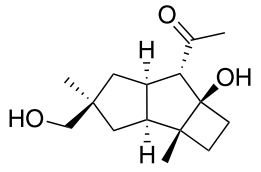

(+)-repraesentin $\mathrm{F}$

\section{(+)-repraesentin}

synthesis and comparison of NMR and OR data ${ }^{68}$

$\mathrm{NMR}^{\mathrm{a} 69}$

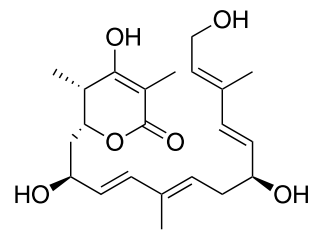

synthesis and comparison of NMR data ${ }^{70}$

hydrolysis and chira HPLC analysis and comparison of OR and NMR data ${ }^{71}$
$(4 S, 5 R)$-2,18-seco-lankacidin B

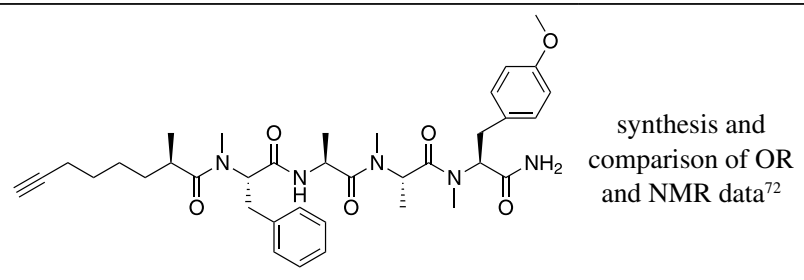

(-)-dragomabin 
Table 1. Absolute configuration reassignment of natural products using synthesis as the main approach (2010-2020) (cont.)

Initial structure
determination
methods

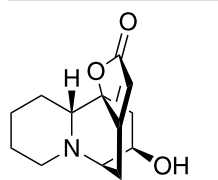

$(+)-(2 R, 7 R, 8 R, 10 S)$-virosine $\mathrm{B}$<smiles>O=C1C=C2C(O)C3CCN4CCCCC4C23O1</smiles>

(-)-(5S,10aS,10bR,12R)-episecurinol A<smiles>COc1cccc(-c2nc(C(=O)NCC(O)c3ccccc3)c(C)o2)c1OC</smiles>

(-)-(7'S)-hinduchelin A

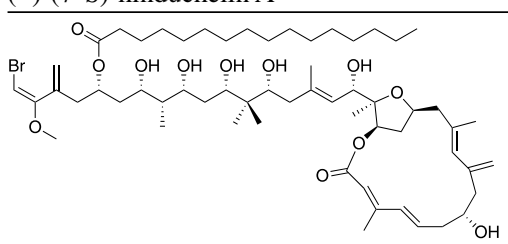

(+)-(7R,13S, 15R,16R,17R,21R,23S,25R,26R,27S,29S)-

phormidolide A<smiles>CC(O)C[C@H]1C=CC[C@@H](CC(=O)CC(=O)O)O1</smiles>

ECD calculations ${ }^{84}$

variable temperature Mosher analysis ${ }^{82}$

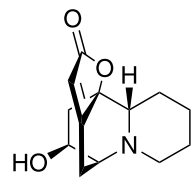

(+)-virosine B

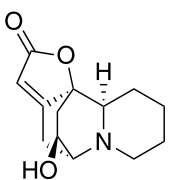

(-)-episecurinol A

ECD calculations $^{80}$<smiles>COc1cccc(-c2nc(C(=O)NCC(O)c3ccccc3)c(C)o2)c1OC</smiles>

$(-)-(7 ' R)$-hinduchelin A

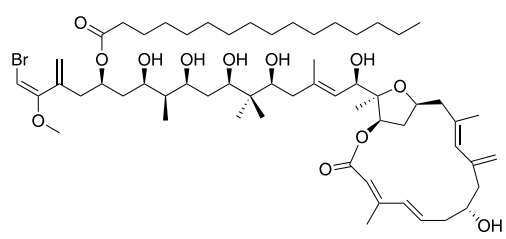

synthesis and comparison of NMR data ${ }^{83}$ synthesis and comparison of $\mathrm{OR}$ and NMR data ${ }^{78}$

synthesis and comparison of OR and NMR data ${ }^{78}$ synthesis and comparison of OR and NMR data ${ }^{81}$

$(21 S, 23 R, 25 S, 26 R, 27 R, 29 R)$-phormidolide A

(-)-(4'R,8' $\left.S, 10^{\prime} R\right)$-monocillin VII<smiles>CCCCCCCC/C=C\CC/C=C/[C@H]1C[C@@H]([C@](O)(CC(=O)OC(C(=O)O)C(CO)C(=O)O)C(=O)O)C(=O)O1</smiles>

hydrolysis and Mosher analysis ${ }^{86}$<smiles>CC(O)C[C@H]1C=CCC(CC(=O)Cc2cc(O)cc(O)c2C(=O)O)O1</smiles>

synthesis and comparison of OR and NMR data ${ }^{85}$<smiles>C/C=C/C1=CC2=CC(=O)[C@@]3(C)OC(=O)C(C(C)=O)C3C2=CO1</smiles>

$(-)-(S)$-trichoflectin chaunopyran A s ${ }^{88}$

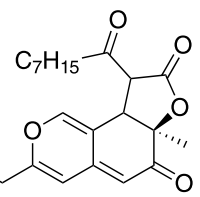
$(+)-(R)$-deflectin $1 \mathrm{~A}$

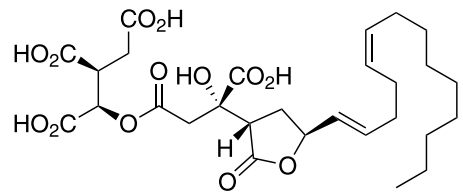

(+)-(3S, $\left.4 S, 6 S, 2^{\prime} R, 3^{\prime} S\right)$-citrafungin A synthesis and comparison of OR and NMR data ${ }^{87}$

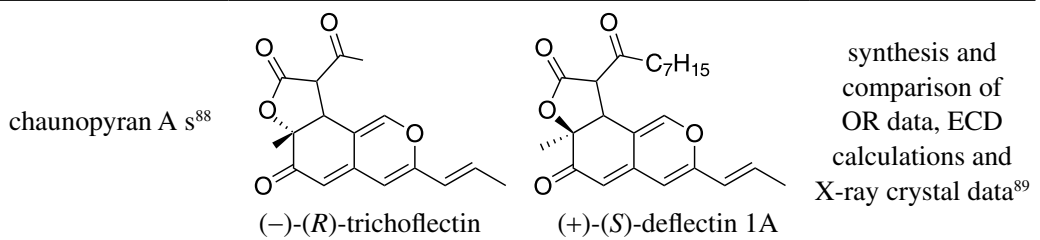


Table 1. Absolute configuration reassignment of natural products using synthesis as the main approach (2010-2020) (cont.)

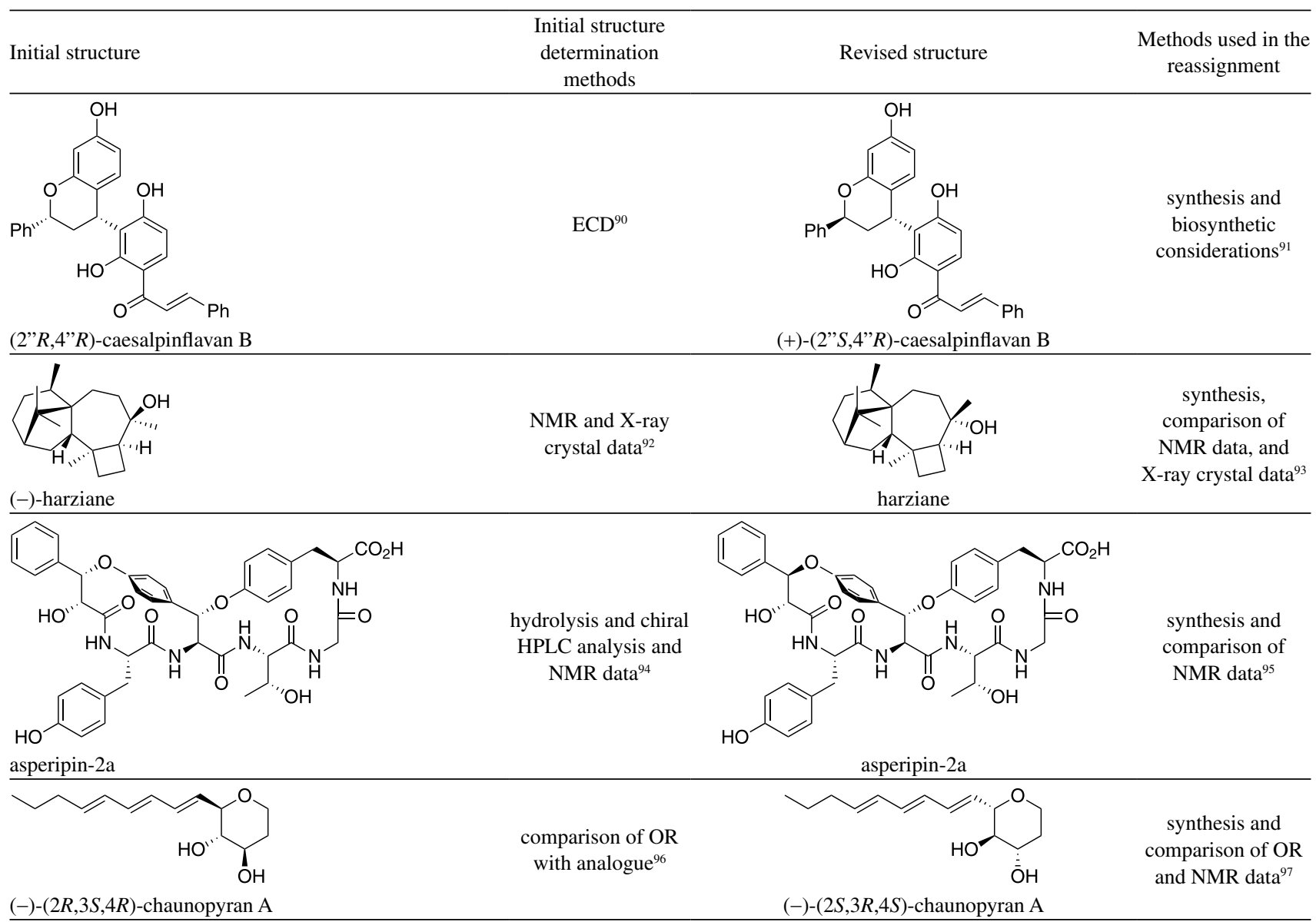

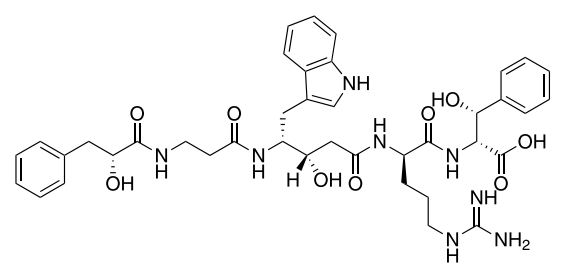

kasumigamide

\section{NMR, hydrolysis, HPLC analysis and chemical derivatization experiments $^{98}$}

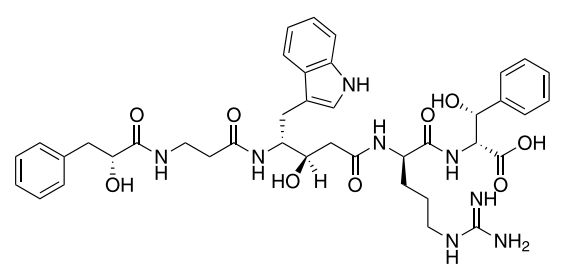

synthesis, hydrolysis and Marfey's analysis ${ }^{99}$

kasumigamide

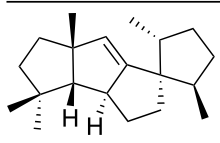

$(-)-(3 R, 6 R, 10 S, 11 R, 14 R)$-spiroviolene

$$
\text { transformation and }
$$$$
\text { enzimatic }
$$
$\mathrm{NMR}^{100}$

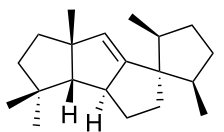

(-)-spiroviolene synthesis, computational investigations and NMR data ${ }^{101}$

${ }^{a}$ Authors mention only the determination of the relative configuration. HPLC: high-performance liquid chromatography; OR: optical rotation; NMR: nuclear magnetic resonance; CD: circular dichroism; ECD: electronic circular dichroism; HRESIMS: high resolution electrospray ionization mass spectrometry; PGME: phenylglycine methyl ester; GC-MS: gas chromatography mass spectrometry; ROESY: rotating frame Overhause effect spectroscopy.

Most of the structural revisions using synthesis as the principal approach determine the $\mathrm{AC}$ of the natural product mainly by comparison of the OR data obtained for the synthetic compounds with those of the natural counterparts. An interesting example is the case of the sesquiterpene lineariifolianone. The AC of this compound, isolated from the plant Inula lineariifolia, was initially determined based on a combination of the modified Mosher method and X-ray crystal data as (-)-( $1 S, 4 R, 5 S, 7 S, 10 S)$-lineariifolianone. ${ }^{73}$ However, in a recent work, Reber et $a l .^{74}$ have reported the total synthesis of lineariifolianone and, based on a comparison of OR and NMR data of the synthetic and the isolated compounds, they suggested that the AC of the natural product had been misassigned. To explain the 
original misassignment, this later work points out that "Mosher ester analysis often gives erroneous results when applied to sterically hindered secondary alcohols". ${ }^{74}$

Although the comparison of OR values between synthetic and natural compounds is widely used, a recent example highlights the risk of $\mathrm{AC}$ assignments based on this approach. ${ }^{102}$ The natural product (+)-frondosin B had its AC originally assigned by total synthesis by different groups, ${ }^{103}$ however conflicting results were observed. In 2018 , Joyce et al. ${ }^{102}$ unambiguously confirmed the AC of this compound as $(+)-(R)-$ frondosin $\mathrm{B}$ using chiroptical methods associated with quantum-mechanical calculations. The authors also discovered that a minor impurity resulting from different synthetic routes was responsible for the conflicting OR values of the synthetic products with the same AC. ${ }^{102}$ Therefore, we strongly discourage the comparison of OR values at single wavelengths as the main method to assign AC of chiral compounds in general.

The careful reading of the articles reported in this review also indicated that the need for stereochemical reassignment was, in many cases, due to previous errors in the relative configuration of the target compound. Two dioxomorpholines, named mollenines $\mathrm{A}$ and $\mathrm{B}$, isolated from the ascostromata of Eupenicillium molle (NRRL 130062), had their relative stereochemistry deduced from nuclear overhauser effect spectroscopy (NOESY) analysis. ${ }^{65}$ Then, the $\mathrm{AC}$ of (-)-mollenine A was assigned by comparing the OR data of its hydrolysis product with that of a standard. ${ }^{65}$ The AC of (-)-mollenine B was assumed to be analogous to that of (-)-mollenine A. Years later, the total synthesis of these compounds led to the revision of their AC. ${ }^{66} \mathrm{As}$ the NMR data of the synthetic and natural (-)-mollenine A were not compatible, an epimer of (-)-mollenine A was synthesized. The NMR and OR data of this epimer showed complete agreement with those reported for the natural compound. Furthermore, a comparison of experimental and calculated ECD spectra for both synthesized compounds supported the $\mathrm{AC}$ reassignment of natural (-)-mollenine A as $3 S, 6 S, 14 S, 16 S .66$

\subsection{Chiroptical methods}

Chiroptical methods, mainly associated with quantummechanical calculations, have been proved to be a powerful and reliable tool for the determination of AC of chiral compounds ${ }^{104}$ and, consequently, this methodology has also been used in several stereochemical revisions of natural products (Table 2).

Table 2. Absolute configuration reassignment of natural products using chiroptical methods as the main approach (2010-2020)

\begin{tabular}{|c|c|c|c|}
\hline Initial structure & $\begin{array}{l}\text { Initial structure determination } \\
\text { method }\end{array}$ & Revised structure & $\begin{array}{l}\text { Method used in the } \\
\text { reassignment }\end{array}$ \\
\hline $\begin{array}{l}\text { (+)-(S)-3,4-dihydro-5-hydroxy-2,7-dimethyl- } \\
\text { 8-(3"'-methyl-2'-butenyl)-2-(4'-methyl- } \\
\text { 6-carboxylic acid }\end{array}$ & ECD and empirical rules ${ }^{105}$ & $\begin{array}{l}\text { (+)-(R)-3,4-dihydro-5-hydroxy- } \\
\text { 2-(4'-dimethyl-8-(3"'-methyl-2"'-butenyl)- } \\
\text { 2H-1-benzopyran-6-carboxylic acid }\end{array}$ & $\begin{array}{l}\text { VCD and ECD associated } \\
\text { with quantum-mechanical } \\
\text { calculations }^{14}\end{array}$ \\
\hline$(-)-(2 S, 13 S)$-brevianamide $\mathrm{M}$ & $\begin{array}{c}\text { X-ray crystal data and } \\
\text { hydrolysis experiments }\end{array}$ & $(-)-(2 R, 13 R)$-brevianamide $\mathrm{M}$ & $\begin{array}{l}\text { VCD, ECD and ORD } \\
\text { associated with quantum- } \\
\text { mechanical calculations }{ }^{107}\end{array}$ \\
\hline$(+)-(7 S, 8 S)$-schizandrin & $\begin{array}{l}\text { NMR and ECD compared } \\
\text { with analogues }{ }^{108}\end{array}$ & $(+)-(7 S, 8 R)$-schizandrin & $\begin{array}{c}\text { VCD and ECD associated } \\
\text { with quantum-mechanical } \\
\text { calculations }{ }^{109}\end{array}$ \\
\hline
\end{tabular}


Table 2. Absolute configuration reassignment of natural products using chiroptical methods as the main approach (2010-2020) (cont.)

\begin{tabular}{|c|c|c|c|}
\hline Initial structure & $\begin{array}{l}\text { Initial structure determination } \\
\text { method }\end{array}$ & Revised structure & $\begin{array}{l}\text { Method used in the } \\
\text { reassignment }\end{array}$ \\
\hline (+)-(3R,4R,6S)-3,6-dihydroxy-1-menthene & biosynthetic considerations ${ }^{110}$ & $(+)-(3 S, 4 S, 6 R)$-3,6-dihydroxy-1-menthene & $\begin{array}{l}\text { VCD associated with } \\
\text { quantum-mechanical } \\
\text { calculations of some } \\
\text { analogues and X-ray crystal } \\
\text { data }{ }^{111}\end{array}$ \\
\hline $\mathrm{OH}$ & $\begin{array}{l}\text { authors drew the structure but } \\
\text { did not mention the } \mathrm{AC}^{112}\end{array}$ & & $\begin{array}{l}\text { VCD associated with } \\
\text { quantum-mechanical } \\
\text { calculations of some } \\
\text { analogues }{ }^{113}\end{array}$ \\
\hline
\end{tabular}

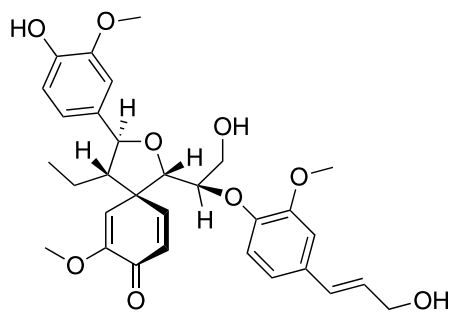

$(-)-\left(7 S, 8 R, 1^{\prime} S, 7^{\prime} S, 8^{\prime} R\right)$-sibiricumin A
ECD calculations using simplified model $^{1113}$ synthesis and comparison of OR data ${ }^{103}$

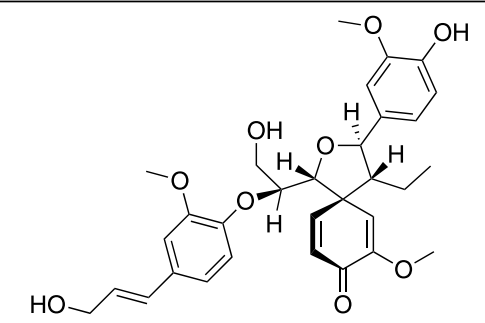

OR and ECD associated with quantum-mechanical calculations $\mathrm{s}^{114}$<smiles>CC1CCC2=C(CCCC2(C)C)c2c1oc1ccccc21</smiles>

(+)-(S)-frondosin B $(-)-\left(7 R, 8 S, 1^{\prime} R, 7^{\prime} R, 8^{\prime} S\right)$-sibiricumin A<smiles>CC1CCC2=C(CCCC2(C)C)c2c1oc1ccccc21</smiles>

$(+)-(R)$-frondosin B exciton coupling ECD of synthetic fragments ${ }^{116}$

(-)-(R)-distaminolyne A OR data ${ }^{115}$

$(-)-(S)$-distaminolyne A<smiles>COc1ccc(CC2c3cc4c(cc3CCN2C)Oc2cc(ccc2OC)OCO4)cc1</smiles>

(+)-(1R,1'S)-cepharanthine degradation methods ${ }^{117}$<smiles>COc1ccc(C[C@H]2c3cc4c(cc3CCN2C)Oc2cc(ccc2OC)OCO4)cc1</smiles>

$(+)-\left(1 R, 1^{\prime} R\right)$-cepharanthine<smiles>C/C=C/C1=CC(=O)C(C)(/C=C/C=C/CC)O1</smiles>

(2S)-14-deoxy-13(14)-dehydroterrefuranone<smiles>CC(O)[C@H](O)/C=C/c1cccc(O)c1C=O</smiles>

$(-)-\left(3^{\prime} R, 4^{\prime} R\right)$-agropyrenol<smiles>C/C=C/C1=CC(=O)[C@@](C)(/C=C/C=C/CC)O1</smiles>

\section{$\mathrm{ECD}^{119}$}

$\mathrm{ECD}^{119} \quad(2 R)-14-\mathrm{de}$

VCD and ECD associated with quantum-mechanical calculations $^{102}$
VCD, ECD and ORD associated with quantummechanical calculations ${ }^{118}$ modified Mosher analysis ${ }^{121}$

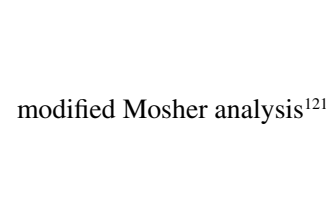

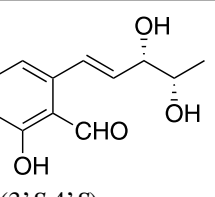

Snatzke's sector rules, modified Mosher analysis of analogue and ECD calculation of analogue $e^{120}$ 
Table 2. Absolute configuration reassignment of natural products using chiroptical methods as the main approach (2010-2020) (cont.)

Initial structure
$\begin{gathered}\text { Initial structure determination } \\ \text { method }\end{gathered}$

${ }^{a}$ Authors corrected the optical rotations values. VCD: vibrational circular dichroism; ECD: electronic circular dichroism; ORD: optical rotatory dispersion; NMR: nuclear magnetic resonance; AC: absolute configuration.

Cepharanthine is a bioactive bisbenzylisoquinoline alkaloid. The $\mathrm{AC}$ of (+)-cepharanthine was originally determined as $1 R, 1^{\prime} S$ using degradation methods. ${ }^{117}$ In 2019, Ren et al. ${ }^{118}$ reassigned the ACs of (+)-cepharanthine and other 13 analogues by comparing experimental and calculated ORD, ECD and VCD spectra.

However, even theoretical calculations can led to AC misassignments. ${ }^{125}$ In order to guarantee the correct determination of $\mathrm{AC}$ by means of quantum chemical calculations, some factors must be considered, such as the methodological approach and the correct prediction of the conformational ensemble of a given molecule. This includes the choice of adequate levels of theory, comprehensive conformational searches, proper optimization of geometry and accurate simulations of the relative energies of the conformers. ${ }^{125}$ Good practices for the correct computation and analysis of chiroptical spectra can be found elsewhere. , $^{8104,125,126}$

Recently, the cathecol derivative hinduchelin A was isolated from Streptoalloteichus hindustanus and its AC was established by interpretation of ECD spectra associated with quantum chemical calculations as $(-)-(7 " S) .{ }^{80}$ One year later, the total synthesis of this compound was achieved and, based on the comparison of NMR and OR data, the stereochemistry of the natural hinduchelin A was reassigned as (-)-(7" $R) .{ }^{81}$ Another case, widely discussed by Grauso et al., ${ }^{125}$ is the assignment of the AC of pestalospirane $\mathrm{B}$ that was determined based on ECD calculations as $3 S, 3^{\prime} S, 12 R, 12^{\prime} R^{59}$ and revised to $3 R, 3^{\prime} R, 12 S, 12^{\prime} S$ by total synthesis, ECD and X-ray analysis. ${ }^{60}$

\subsection{NMR methods}

Few reports used NMR methods as the main methodology to reassign the AC of natural products (Table 3) over the considered time span. The case of the polyketide macrolactams heronamides A-C is an interesting example. These compounds were isolated from a Streptomyces sp. and had their structures determined based on spectroscopic analysis, Mosher's method and biosynthetic considerations. ${ }^{127}$ In 2013, the AC of heronamide A was reassigned by interpretation of the NOESY data and modified Mosher analysis, since the original NMR data were not in agreement with the proposed stereochemistry. However, in contrast to the former work where only the $17-\mathrm{OH}$ was esterified, in the latter, heronamide A was converted to 9,17-bis- $(S)$ - or 9,17-bis-( $R$ )-MTPA ( $\alpha$-methoxy$\alpha$-trifluoromethylphenylacetic acid) derivatives. Based on this, the AC of natural (-)-heronamide A was revised to $2 S, 7 S, 8 S, 9 R, 12 R, 15 S, 16 R, 17 S, 19 R .{ }^{128}$

Table 3. Absolute configuration reassignmets of natural products using NMR method as the main approach (2010-2020)

Initial structure


Table 3. Absolute configuration reassignmets of natural products using NMR method as the main approach (2010-2020) (cont.)

(It)

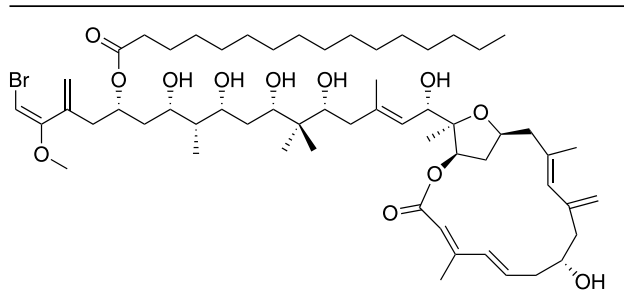

(+)-(7R,13S,15R,16R,17R,21R,23S,25R,26R,27S,29S)-

phormidolide A

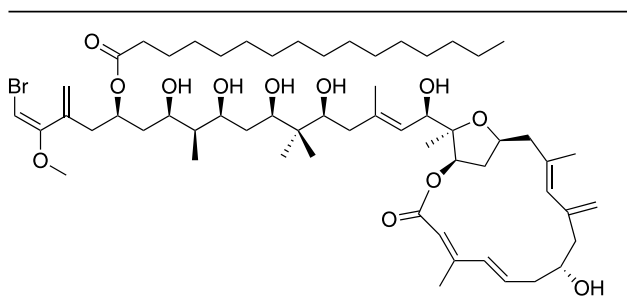

variable temperature

Mosher analysis $^{82}$ synthesis and comparison of NMR data ${ }^{83}$

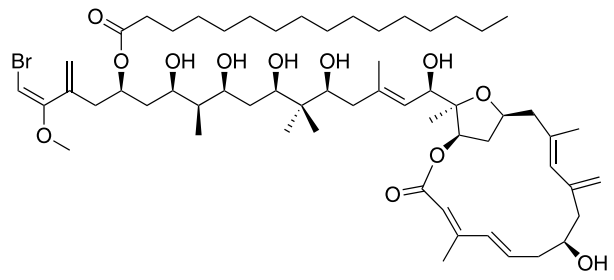

phormidolide $\mathrm{A}$
GIAO NMR

calculations and anisotropic NMR $^{135}$

$(21 S, 23 R, 25 S, 26 R, 27 R, 29 R)$-phormidolide A<smiles>CC(O)[C@H]1C=C[C@H]2OC(=O)C=C[C@H]2O1</smiles>

(+)-(4aS,6R,8aS,9S)-diplopyrone
ECD and OR calculations ${ }^{136}$

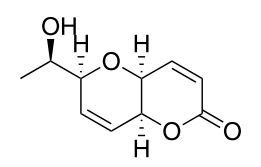

(+)-(4aS,6S,8aS,9R)-diplopyrone

OR: optical rotation; NMR: nuclear magnetic resonance; ECD: electronic circular dichroism; GIAO: gauge-including atomic orbitals.

\subsection{X-ray crystallography}

$\mathrm{X}$-ray crystallography was employed as the main approach for the AC reassignment of natural products in three publications (Table 4) only. Despite being a powerful tool for AC determination, the difficulty in obtaining single crystals with suitable quality from natural products can explain the low number of reports using this methodology. 
Table 4. Absolute configuration reassignments of natural products using X-ray crystallography data as the main approach (2010-2020)

Initial structure
determination
method

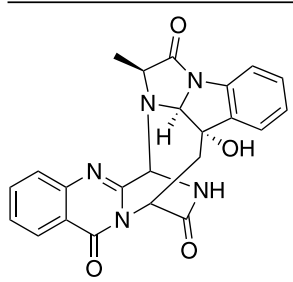

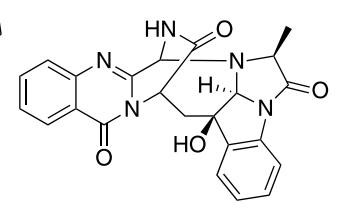

NMR data and comparison with analogues $^{123,142}$<smiles>CC1C(=O)N2c3ccccc3C3(O)CC4C(NC14)C(=O)N2C3C</smiles>

(+)-(3S,14S,16S,17S,19S)-cottoquinazoline $\mathrm{E}$

$X$-ray crystal data, NMR and $\mathrm{ECD}^{124}$

(+)-cottoquinazoline $\mathrm{E}$<smiles></smiles>

(+)-cottoquinazoline $\mathrm{G}$ comparison of OR with analogues and biosynthesis considerations $^{142}$<smiles>CC1NC2c3ccccc3N2C2(CC3NC(=O)C(O)C3C2)c2nc3ccccc3c(=O)n21</smiles>

(+)-(3S,14S,16S,17S,19S)-cottoquinazoline G

${ }^{a}$ Authors mention only the determination of the relative configuration. OR: optical rotation; NMR: nuclear magnetic resonance; ECD: electronic circular dichroism.

\section{Quantum Chemical Calculations in Struc- ture Elucidation of Natural Products}

\subsection{NMR calculations}

A careful analysis of the articles dealing with the revision of the $\mathrm{AC}$ of chiral natural products covered by the present review revealed some approaches that can commonly lead to misassignments. One particularly critical aspect related to the $\mathrm{AC}$ determination is the correct assignment of the relative configuration.

The structural elucidation of natural products, including the relative configuration determination, is predominantly based on NMR experiments. ${ }^{143}$ Even with continuous advances in the field, misinterpretation of NMR data is still frequently observed in natural product chemistry. ${ }^{144}$ The presence of sample impurities, signal ambiguities and high molecular complexity can lead to an incorrect interpretation of the NMR data and consequent structural misassignments. ${ }^{145}$ One way to ensure the correct determination of relative configuration of molecules with more than one chiral center is the use of computational techniques. Quantum chemical calculations of NMR properties have become popular over the last years and nowadays such studies are routinely found in the literature. Such popularity can be ascribed to the possibility to discriminate closely related stereostructures for complex natural product molecules. ${ }^{144}$ This approach greatly 
improves the quality of structural clarification regarding relative stereochemistry and therefore helps to prevent errors in $\mathrm{AC}$ determinations.

One of the most common approaches to determine relative configuration of natural products from isotropic NMR calculations involve the simulation of ${ }^{1} \mathrm{H}$ and/or ${ }^{13} \mathrm{C}$ shielding constants (and thus chemical shifts) for all possible stereoisomers of a given molecule. Coupling constants can also be simulated. Routine methods involve gauge-including atomic orbitals (GIAOs) and model chemistries such as mPW1PW91/6-311+G(2d,p), PBE0/6-311+G(2d,p) or B3LYP/6-31+G(d,p) on B3LYP/6-31+G(d,p) or M062X/6-31+G(d,p) geometries. ${ }^{146}$ NMR calculation results can then be translated into structural information by assessing the goodness of fit between computed and experimental data. It can be done by means of artificial intelligence methods ${ }^{147}$ or by determining manually the most likely structure within a set of suitable candidates. Further analysis using the CP3 parameter ${ }^{148}$ or DP4 probability methods, ${ }^{149}$ which are the first of a series of useful tools, ${ }^{150}$ greatly help in the diastereoisomeric discrimination of complex molecules. Several comprehensive review articles are available in the literature that provide more in-depth information on the accurate simulation of NMR data. ${ }^{144-146,151}$

\subsection{Chiroptical properties calculations}

As mentioned before, another important source of error in the AC determination of natural products is the comparison of the OR and/or ECD experimental data with those described for analogous molecules or even spectral analyses based on empirical rules. One way to prevent misassignments is the comparison of experimental data with density functional theory (DFT)-predicted spectra ${ }^{8,104}$ as well as the use non-empirical methods ${ }^{152}$ or quantumchemically validated spectra-structure relationships. ${ }^{15,153}$ The comparison between calculated and experimental data greatly assists the unambiguous interpretation of experimental spectra by providing information on the origin of electronic or vibrational transitions as well as on the influence of conformational flexibility, solvation, and minor structural variations to the spectral shape. Notable developments in ab initio to predict theoretical spectra incorporated in commercially available software have contributed to a number of unambiguous AC determinations of natural products. ${ }^{104}$

DFT-level calculations are generally the main computational method used in the quantum mechanical prediction of chiroptical spectroscopic properties. Despite a large number of DFT functionals available, B3LYP together with the 6-31G(d) basis set, either in gas phase or with implicit solvation, is still the most widely used. ${ }^{125}$ However, as B3LYP can provide inaccurate evaluations of conformer energy profiles, alternative functionals should be considered, such as B3PW91 or wB97XD. ${ }^{125}$ The choice of the most appropriate model chemistry will depend on the chiroptical property of interest. While B3LYP/6-31G(d) may suffice for some VCD spectral calculations, in the case of ECD for example, long-range correct functionals such as CAM-B3LYP and triple-zeta basis sets are recommended. A number of review articles can be found in the literature that provide detailed information and good practices for the accurate calculations of chiroptical properties. ${ }^{8,104,125,126}$

\section{Conclusions}

The structural elucidation of natural products is a crucial part of the routine of research laboratories in this area. The complete structural characterization of natural compounds, however, including the exact spatial arrangement of their atoms, is still one of the most challenging steps. The methodologies used to assign the AC have evolved considerably and become more widely available, which has led to the AC reassignment of many natural products over the last decade, as demonstrated herein. The partnership between natural product chemistry and synthetic organic chemistry was the most used approach, followed by chiroptical methods, mainly associated with DFT calculations, and then NMR. It is worth mentioning that the unambiguous determination of the relative configuration of molecules with several stereogenic centers was a fundamental step for the correct (re)assignment of the AC. Incorrect relative configurations were responsible for many of the errors reported in the determination of the $\mathrm{AC}$ of natural compounds.

Thus, rigorous spectroscopic work using the available methods, either alone or in combination, is still the best approach for the unambiguous assignment of both relative and absolute configurations. These steps can be considered indispensable for the complete attribution of the structure of a natural product and provide further subsidies for biological tests and investigations of biosynthetic pathways. Finally, as already mentioned above, the assignments of AC based solely on comparison of OR values are strongly discouraged. Even in cases where the synthetic methodology affords the unambiguous $\mathrm{AC}$ of a given target molecule, the (re)assignment of the natural counterpart may not be reliable if only OR is considered. Despite of its simplicity and ease of use, OR values at single wavelengths may vary widely upon changes in solvent, sample concentration, and purity. As alternatives, methods 
that provide information over a range of frequencies, such as ORD, ECD, VCD, ROA should be used instead.

\section{Acknowledgments}

The authors are thankful to the São Paulo Research Foundation (FAPESP) (grant No. 2019/22319-5) and Rio de Janeiro Research Foundation (FAPERJ) (grant No. 211.319-2019) for funding and to the Coordination of Improvement of Higher Education Personnel (CAPES, Finance Code 001) for scholarships to ANLB (No. 88887.313278/2019-00).

\section{Author Contributions}

Andrea N.L. Batista was responsible for conceptualization, investigation, supervision, writing: original draft, review and editing; Bianca R. P. Angrisani for investigation, writing: original draft, review and editing; Maria E. D. Lima for investigation, writing: original draft, review and editing; Stephanie M. P. da Silva for investigation, writing: original draft, review and editing; Vitória H. Schettini for investigation, writing: original draft, review and editing; Higor A. Chagas for investigation, writing: original draft, review and editing; Fernando M. dos Santos Jr. for funding acquisition, writing: review and editing; João M. Batista Jr. for conceptualization, investigation, project administration, supervision, visualization, funding acquisition, writing: original draft, review and editing; Alessandra L. Valverde for conceptualization, investigation, project administration, supervision, visualization, writing: original draft, review and editing.

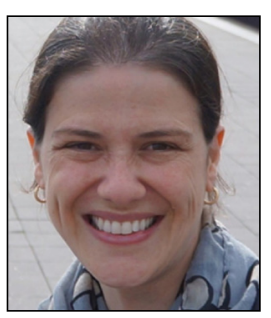

Andrea Batista is a postdoctoral researcher in the Institute of Chemistry at Fluminense Federal University, Brazil. She received a BSc in Pharmacy-Biochemistry (1999) from São Paulo State University (UNESP), Brazil, and $M S c$ (2001) and PhD (2005) degrees in chemistry from the same university, supervised by Prof Massayoshi Yoshida. Over the years, she also worked as a postdoc at the Institute of Chemistry at UNESP and Department of Chemistry at UFSCar. In 2013, she was appointed Visiting Scientist at the University of Manchester. Her research interests involve isolation and stereostructural determination of natural products mainly through chiroptical methods associated with quantum-mechanical calculations.

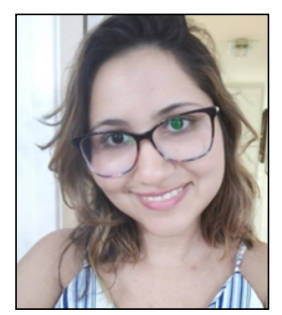

Bianca Roberta P.Angrisani is an Industrial Chemistry undergraduate student at Fluminense Federal University, Brazil. As a scientific initiation student in the Institute of Chemistry at Fluminense Federal University, she was involved in projects focused on the chemical evaluation of bioactive fractions obtained from plants and marine natural products. Currently, her project involves the use of truncated models for calculating chiroptic properties of natural products.

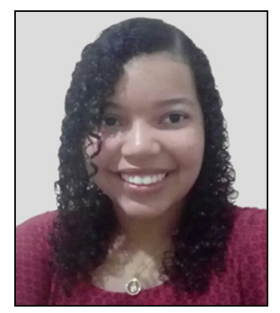

Maria Emanuelle D. Lima is a master's student in the Chemistry Institute at Fluminense Federal University, Brazil. She received a BSc in Chemistry (2019) from Rio de Janeiro Federal Institute of Education, Science, and Technology (IFRJ), Brazil. During graduation she was an intern at the Oswaldo Cruz Foundation (FIOCRUZ, 2017-2019), working with quality control of medicines. In the same period, she worked with the application of plant extracts in photoprotective formulations, as a student of scientific initiation at IFRJ. Her research interests involve isolation and stereostructural determination of natural products mainly substances with possible medicinal applications.

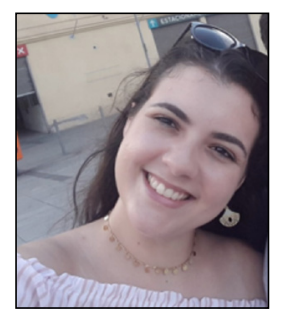

Stephanie M. P. da Silva is a pharmacy undergraduate student at Fluminense Federal University, Brazil. She was a monitor of the discipline of Phytotherapy (2019) at the Faculty of Pharmacy at Fluminense Federal University, Brazil. She does scientific initiation in the area of marine natural products in the Institute of Chemistry at Fluminense Federal University, Brazil.

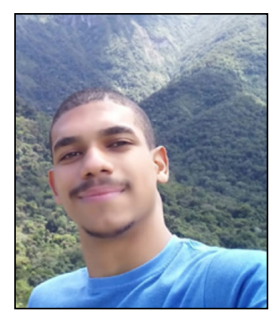

Higor A. Chagas is an undergraduate student in chemistry (bachelor's) at Universidade Federal Fluminense (UFF), Brazil. He is part of the LAPROMAR natural products laboratory as a student of scientific initiation, with the research project Standardization in the extraction of natural marine products and their biological assessments since 2018 under the guidance of researcher Alessandra L. Valverde (UFF). 


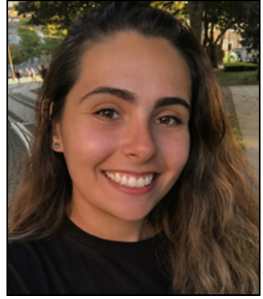

Vitória H. Schettini is an undergraduate student in nutrition at Fluminense Federal University, Brazil. She participated in UFF's 2019 Exchange Program at the University of Porto, Portugal. She did scientific initiation from 2018 to 2019 at LABAFs, Functional Food Laboratory, in Federal University of Rio de Janeiro, Brazil. And now she is part of the LAPROMAR natural products laboratory under the guidance of researcher Alessandra L. Valverde as a student of scientific initiation with the research project Standardization in the extraction of natural marine products and their biological assessments.

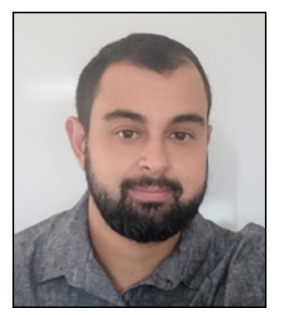

Fernando Martins obtained his PhD (2016) from Natural Products Research Institute at Federal University of Rio de Janeiro, Brazil, under the supervision of Prof Mauro Amorim. He worked as a visiting scholar at Vanderbilt University (2015) in Prof Prasad Polavarapu's group. Following postdoctoral work (2017) at São Carlos Federal University, Brazil, under the supervision of Profs Quezia Cass and João M. Batista Jr., in 2018 he joined the Institute of Chemistry at Fluminense Federal University, Brazil, where he currently is an adjunct Professor. Fernando's research specializes in structure elucidation of natural products by means of computational spectroscopy, mainly NMR and electronic and vibrational circular dichroism.

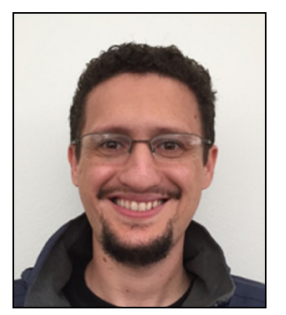

João $\boldsymbol{M}$. Batista Jr. received a BSc in Pharmaceutical Sciences (2007) and a PhD in Chemistry (2012) from UNESP, Brazil. During 2009-2010 he was appointed Visiting Research Scholar at Syracuse University, USA. He then worked as a postdoctoral fellow at UNESP (2012-2015) with a period as Visiting Scientist at the University of Manchester (2012-2013). In 2015, he joined UFSCar, Brazil, to lead the first Vibrational Optical Activity research group in South America. Currently, he works as an assistant professor of chemistry at UNIFESP, in São José dos Campos, Brazil. His research involves stereochemical studies of small molecules and macromolecules using chiroptical methods and quantum-chemical calculations.

Alessandra Leda Valverde is an Associate Professor in the Institute of Chemistry at Fluminense Federal University,

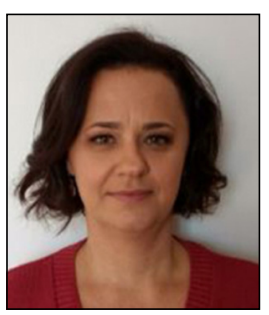

Brazil. She received a $B S c$ in Industrial Chemistry (1993) and MSc in Organic Chemistry (1996) from Fluminense Federal University, Brazil. Her PhD (1999) degrees in Science at Rio de Janeiro Federal University. Over the years, she also worked as P\&D Researcher at FIOCRUZ (1999-2004) and as a postdoc at Department of Chemistry at São Carlos Federal University in 2017. She supervises postdoctoral, doctoral, master's and undergraduate students. Her research interests involve isolation and stereostructural determination of bioactive natural products.

\section{References}

1. Newman, D. J.; Cragg, G. M.; J. Nat. Prod. 2016, 79, 629.

2. Colegate, S. M.; Molyneux, R. J.; Bioactive Natural Products: Detection, Isolation, and Structural Determination, $2^{\text {nd }}$ ed.; Taylor and Francis: Boca Raton, USA, 2008; Koskinen, A. M. P.; Asymmetric Synthesis of Natural Products, $2^{\text {nd }}$ ed.; Wiley: Chichester, USA, 2012; Newman, D. J.; Cragg, G. M.; J. Nat. Prod. 2020, 83, 770 .

3. Lovering, F.; Bikker, J.; Humblet, C.; J. Med. Chem. 2009, 52, 6752; Camp, D.; Garavelas, A.; Campitelli, M.; J. Nat. Prod. 2015, 78, 1370.

4. de Luca, V.; Salim, V.; Atsumi, S. M.; Yu, F.; Science 2012, 336, 1658.

5. Nguyen, L. A.; He, H.; Pham-Huy, C.; Int. J. Biomed. Sci. 2006, 2, 85; Jayakumar, R.; Vadivel, R.; Ananthi, N.; Org. Med. Chem. Int. J. 2018, 5, 555661.

6. Kasprzyk-Hordern, B.; Chem. Soc. Rev. 2010, 39, 4466.

7. Calcaterra, A.; D' Acquarica, I.; J. Pharm. Biomed. Anal. 2018, 147, 323.

8. Polavarapu, P. L.; Santoro, E.; Nat. Prod. Rep. 2020, 37, 1661.

9. Flack, H. D.; Bernardinelli, G.; Chirality 2008, 20, 681; Harada, N.; Chirality 2008, 20, 691; Parsons, S.; Tetrahedron: Asymmetry 2017, 28, 1304.

10. Seco, J. M.; Quinoa, E.; Riguera, R.; Chem. Rev. 2004, 104, 17; Wenzel, T. J.; Chisholm, C. D.; Chirality 2011, 23, 190; Seco, J. M.; Quinoa, E.; Riguera, R.; Chem. Rev. 2012, 112, 4603.

11. Sadlej, J.; Dobrowolski, J. C.; Rode, J. E.; Chem. Soc. Rev. 2010, 39, 1478.

12. Petrovic, A. G.; Navarro-Vázquez, A.; Alonso-Gómez, J. L.; Curr. Org. Chem. 2010, 14, 1612.

13. Freedman, T. B.; Cao, X.; Oliveira, R. V.; Cass, Q. B.; Nafie, L. A.; Chirality 2003, 15, 196; Stephens, P. J.; Pan, J. J.; Devlin, F. J.; Urbanová, M.; Hájíček, J.; J. Org. Chem. 2007, 72, 2508; Kwit, M.; Gawronski, J.; Boyd, D. R.; Sharma, N. D.; Kaik, M.; O’Ferrall, R. A. M.; Kudavalli, J. S.; Chem. Eur. J. 2008, 
14, 11500; Nakahashi, A.; Yaguchi, Y.; Miura, N.; Emura, M.; Monde, K.; J. Nat. Prod. 2011, 74, 707.

14. Batista, J. M.; Batista, A. N. L.; Rinaldo, D.; Vilegas, W.; Cass, Q. B.; Bolzani, V. S.; Kato, M. J.; López, S. N.; Furlan, M.; Nafie, L. A.; Tetrahedron: Asymmetry 2010, 21, 2402.

15. dos Santos Jr., F. M.; Bicalho, K. U.; Calisto, Í. H.; Scatena, G. S.; Fernandes, J. B.; Cass, Q. B.; Batista Jr., J. M.; Org. Biomol. Chem. 2018, 16, 4509.

16. Nicolaou, K. C.; Snyder, S. A.; Angew. Chem., Int. Ed. 2005, 44, 1012; Suyama, T. L.; Gerwick, W. H.; McPhail, K. L.; Bioorg. Med. Chem. 2011, 19, 6675.

17. Teruya, T.; Sasaki, H.; Fukazawa, H.; Suenega, K.; Org. Lett. 2009, 11, 5052.

18. Gao, X.; Liu, Y.; Kwong, S.; Xu, Z.; Ye, T.; Org. Lett. 2010, 12, 3018.

19. Jang, J.; Asami, Y.; Jang, J.; Kim, S.; Moon, D. O.; Shin, K.; Hashizume, D.; Muroi, M.; Saito, T.; Oh, H.; Kim, B. Y.; Osada, H.; Ahn, J. S.; J. Am. Chem. Soc. 2011, 133, 6865.

20. Deng, J.; Zhu, B.; Lu, Z.; Yu, H.; Li, A.; J. Am. Chem. Soc. 2012, 134, 920 .

21. Grkovic, T.; Blees, J. S.; Colburn, N. H.; Schmid, T.; Thomas, C. L.; Henrich, C. J.; McMahon, J. B.; Gustafson, K. R.; J. Nat. Prod. 2011, 74, 1015.

22. Wang, Y.; O’Doherty, G. A.; J. Am. Chem. Soc. 2013, 135, 9334.

23. Abdel-Mageed, W. M.; Ebel, R.; Valeriote, F. A.; Jaspars, M.; Tetrahedron 2010, 66, 2855.

24. Holmes, M. T.; Britton R.; Chem.- Eur. J. 2013, 19, 12649; Shepherd, D. J.; Broadwith, P. A.; Dyson, B. S.; Paton, R. S.; Burton, J. W.; Chem.- Eur. J. 2013, 19, 12644.

25. Yazawa, H.; Imai, H.; Suzuki, K.; Kadota, S.; Saito, T.; U.S. Patent 4,912,215 1990; Imai, Y.; Yazawa, S.; Saito, T.; Japanese Patent JP01168671 1989; Imai, Y.; Yazawa, S.; Suzuki, K.; Yamaguchi, Y.; Shibazaki, M.; Saito, T.; Japanese Patent JP01106884 1989.

26. Yang, S.; Xi, Y.; Zhu, R.; Wang, L.; Chen, J.; Yang, Z.; Org. Lett. 2013, 15, 812.

27. Wu, Q.-X.; Crews, M. S.; Draskovic, M.; Sohn, J.; Johnson, T. A.; Tenney, K.; Valeriote, F. A.; Yao, X.-J.; Bjeldanes, L. F.; Crews, P.; Org. Lett. 2010, 12, 4458.

28. Zhao, J.-C.; Yu, S.-M.; Liu, Y.; Yao, Z.-J.; Org. Lett. 2013, 15, 4300; Zhao, J.-C.; Yu, S.-M.; Qiu, H.-B.; Yao, Z.-J.; Tetrahedron 2014, 70, 3197.

29. Salomon, C. E.; Williams, D. H.; Lobkovsky, E.; Clardy, J. C.; Faulkner, J.; Org. Lett. 2002, 4, 1699.

30. Fuwa, H.; Muto, T.; Sekine, K.; Sasaki, M.; Chem. - Eur. J. 2014, 20, 1848; Zhang, F.-M.; Tu, Y.-Q.; Tetrahedron Lett. 2014, 55, 3784.

31. Tokhtabaeva, G. M.; Sheichenko, V. I.; Yartseva, I. V.; Tolkachev, O. N.; Khim. Prir. Soedin. 1987, 23, 727.

32. Beaulieu, M.; Ottenwaelder, X.; Canesi, S.; Chem.- Eur. J. 2014, 20,7581
33. Luesch, H.; Yoshida, W. Y.; Harrigan, G. G.; Doom, J. P.; Moore, R. E.; Paul, V. J.; J. Nat. Prod. 2002, 65, 1945.

34. Fuwa, H.; Okuaki, Y.; Yamagata, N.; Sasaki, M.; Angew. Chem., Int. Ed. 2015, 54, 868.

35. Liu, Y.; Kubo, M.; Fukuyama, Y.; J. Nat. Prod. 2012, 75, 2152.

36. Lan, P.; Banwell, M. G.; Ward, J. S.; Willis, A. C.; Org. Lett. 2014, 16, 228.

37. Woo, K. W.; Moon, E.; Kwon, O. W.; Lee, S. O.; Kim, S. Y.; Choi, S. Z.; Son, M. W.; Lee, K. R.; Bioorg. Med. Chem. Lett. 2013, 23, 3806.

38. Yadav, J. S.; Singh, V. K.; Thirupathaiah, B.; Bal Reddy, A.; Tetrahedron Lett. 2014, 55, 4427.

39. Sikorska, J.; Hau, A. M.; Anklin, C.; Parker-Nance, S.; DaviesColeman, M. T.; Ishmael, J. E.; McPhail, K. L.; J. Org. Chem. 2012, 77, 6066

40. Lei, H.; Yan, J.; Yu, J.; Liu, Y.; Wang, Z.; Xu, Z.; Ye, T.; Angew. Chem., Int. Ed. 2014, 53, 6533; Willwacher, J.; Heggen, B.; Thiel, C. W.; Fìrstner, A.; Chem. - Eur. J. 2015, 21, 10416.

41. Liu, Y.; Hu, Z.; Lin, X.; Lu, C.; Shen, Y.; Nat. Prod. Res. 2013, 27, 2100.

42. Yadav, J. S.; Dutta, P.; Ganganna, B.; Srinivas, E.; Eur. J. Org. Chem. 2015, 2015, 6891.

43. Matthew, S.; Salvador, L. A.; Schupp, P. J.; Paul, V. J.; Luesch, H.; J. Nat. Prod. 2010, 73, 1544.

44. Chang, C.; Stefan, E.; Taylor, R. E.; Chem. - Eur. J. 2015, 21, 10681.

45. Ueoka, R.; Ise, Y.; Ohtsuka, S.; Okada, S.; Yamori, T.; Matsunaga, S.; J. Am. Chem. Soc. 2010, 132, 17692.

46. Kuranaga, T.; Mutoh, H.; Mutoh, H.; Sesoko, Y.; Gotto, T.; Matsunaga, S.; Inoue, M.; J. Am. Chem. Soc. 2015, 137, 9443.

47. Iwasaki, A.; Ohno, O.; Sumimoto, S.; Suda, S.; Suenaga, K.; Tetrahedron Lett. 2014, 55, 4126.

48. Takayanagi, A.; Iwasaki, A.; Suenaga, K.; Tetrahedron Lett. 2015, 56, 4947.

49. Yan, X.-H.; Gavagnin, M.; Cimino, G.; Guo, Y.-W.; Tetrahedron Lett. 2007, 48, 5313.

50. Takamura, H.; Kikuchi, T.; Endo, N.; Fukuda, Y.; Kadota, I.; Org. Lett. 2016, 18, 2110.

51. Haenni, A. L.; Robert, M.; Vetter, W.; Roux, L.; Barbier, M.; Lederer, E.; Helv. Chim. Acta 1965, 48, 78.

52. Liao, D.; Yang, S.; Wang, J.; Zhang, J.; Hong, B.; Wu, F.; Lei, X.; Angew. Chem., Int. Ed. 2016, 55, 429.

53. Matthew, S.; Schupp, P. J.; Luesch, H.; J. Nat. Prod. 2008, 71, 1113.

54. Wu, P.; Cai, W.; Chen, Q.-Y.; Xu, S.; Yin, R.; Li, Y.; Zhang, W.; Luesch, H.; Org. Lett. 2016, 18, 5400.

55. Koyama, K.; Hirasawa, Y.; Nugroho, A. E.; Kaneda, T.; Hoe, T. C.; Chan, K.-L.; Morita, H.; Tetrahedron 2012, 68, 1502.

56. Yu, K.; Gao, B.; Liu, Z.; Ding, H.; Chem. Commun. 2016, 52, 4485.

57. Takahashi, M.; Koyama, K.; Natori, S.; Chem. Pharm. Bull. 1990, 38, 625 . 
58. Makrerougras, M.; Coffinier, R.; Oger, S.; Chevalier, A.; Sabot, C.; Franck, X.; Org. Lett. 2017, 19, 4146.

59. Kesting, J. R.; Olsen, L.; Staerk, D.; Tejesvi, M. V.; Kini, K. R.; Prakash, H. S.; Jaroszewski, J. W.; J. Nat. Prod. 2011, 74, 2206.

60. Badrinarayanan, S.; Squire, C. J.; Sperry, J.; Brimble, M. A.; Org. Lett. 2017, 19, 3414.

61. Yasuda, T.; Araki, A.; Kubota, T.; Ito, J.; Mikami, Y.; Fromont, J.; Kobayashi, J.; J. Nat. Prod. 2009, 72, 488.

62. van Rensburg, M.; Copp, B.; Barker, D.; Eur. J. Org. Chem. 2018, 2018, 3065.

63. Anjaneyulu, A. S. R.; Venugopal, M. J. R. V.; Sarada, P.; Rae, C. V.; Clardy, J.; Lobkovsky, E.; Tetrahedron Lett. 1998, 39, 135.

64. Nannini, L. J.; Nemat, S. J.; Carreira, E. M.; Angew. Chem., Int. Ed. 2018, 57, 823.

65. Wang, H.; Gloer, J. B.; Wicklow, D. T.; Dowd, P. F.; J. Nat. Prod. 1998, 61, 804.

66. Shiomi, S.; Wada, K.; Umeda, Y.; Kato, H.; Tsukamoto, S.; Ishikawa, H.; Bioorg. Med. Chem. Lett. 2018, 28, 2766.

67. Kashiwabara, M.; Kamo, T.; Makabe, H.; Shibata, H.; Hirota, M.; Biosci., Biotechnol., Biochem. 2006, 70, 1502.

68. Ferrer, S.; Echavarren, A. M.; Org. Lett. 2018, 20, 5784.

69. Lu, C.; Li, J.-M.; Qi, H.; Zhang, H.; Zhang, J.; Xiang, W.-S.; Wang, J.-D.; Wang, X.-J.; J. Antibiot. 2018, 71, 397.

70. Yao, Y.; Cai, L.; Seiple, I. B.; Angew. Chem., Int. Ed. 2018, 57, 13551.

71. McPhail, K. L.; Correa, J.; Linigton, R. G.; González, J.; OrtegaBarría, E.; Cpson, T. L.; Gerwick, W. H.; J. Nat. Prod. 2007, $70,984$.

72. Ye, B.; Jiang, P.; Zhang, T.; Sun, Y.; Hao, X.; Cui, Y.; Wang, L.; Chen, Y.; Mar. Drugs 2018, 16, 338.

73. Nie, L.-Y.; Qin, J.-J.; Huang, Y.; Yan, L.; Liu, Y.-B.; Pan, Y.-X.; Jin, H.-Z.; Zhang, W.-D.; J. Nat. Prod. 2010, 73, 1117.

74. Reber, K. P.; Gilbert, I. W.; Strassfeld, D. A.; Sorensen, E. J.; J. Org. Chem. 2019, 84, 5524.

75. Ciminiello, P.; Dell'Aversano, C.; Fattorusso, E.; Forino, M.; Magno, S.; Di Rosa, M.; Ianaro, A.; Poletti, R.; J. Am. Chem. Soc. 2002, 124, 13114.

76. Sondermann, P.; Carreira, E. M.; J. Am. Chem. Soc. 2019, 141, 10510.

77. Wang, G.; Wang, Y.; Li, Q.; Liang, J.; Zhang, X.; Yao, X.; Ye, W.; Helv. Chim. Acta 2008, 91, 1124.

78. Antien, K.; Lacambra, A.; Cossío, F. P.; Massip, S.; Deffieux, D.; Pouységu, L.; Peixoto, A. P.; Quideau, S.; Chem. - Eur. J. 2019, 25, 11574.

79. Quin, S.; Liang, J.; Guo, Y.; Helv. Chim. Acta 2009, 92, 399.

80. He, F.; Nakamura, H.; Hoshino, S.; Chin, J. S. F.; Yang, L.; Zhang, H.; Hayashi, F.; Abe, I.; J. Nat. Prod. 2018, 81, 1493.

81. Childress, E. S.; Garrison, A. T.; Sheldon, J. R.; Skaar, E. P.; Lindsley, C. W.; J. Org. Chem. 2019, 84, 6459.
82. Williamson, R. T.; Boulanger, A.; Vulpanovici, A.; Roberts, M. A.; Gerwick, W. H.; J. Org. Chem. 2002, 67, 7927.

83. Lam, N. Y. S.; Muir, G.; Challa, V. R.; Britton, R.; Paterson, I.; Chem. Commun. 2019, 55, 9717.

84. Xu, L.; Wu, P.; Xue, J.; Molnar, I.; We, X.; J. Nat. Prod. 2017, $80,2215$.

85. Mallampudi, N. A.; Srinivas, B.; Reddy, J. G.; Mohapatra, D. K.; Org. Lett. 2019, 21, 5952.

86. Singh, S. B.; Zink, D. L.; Doss, G. A.; Polishook, J. D.; Ruby, C.; Register, E.; Kelly, T. M.; Bonfiglio, C.; Williamson, J. M.; Kelly, R.; Org. Lett. 2004, 6, 337.

87. Chen, Z.; Robertson, A.; White, J. M.; Rizzacasa, M. A.; Org. Lett. 2019, 21, 9663.

88. Anke, H.; Kemmer, T.; Höfle, G.; J. Antibiot. 1981, 34, 923; Thines, E.; Anke, H.; Sterner, O.; J. Nat. Prod. 1998, 61, 306.

89. Pyser, J. B.; Dockrey, S. A. B.; Benítez, A. R.; Joyce, L. A.; Wiscons, R. A.; Smith, J. L.; Narayan, A. R. H.; J. Am. Chem. Soc. 2019, 141, 18551.

90. Zhang, L.-J.; Bi, D.-W.; Hu, J.; Mu, W.-H.; Li, Y.-P.; Xia, G.-H.; Yang, L.; Li, X.-N.; Liang, X.-S.; Wang, L.-Q.; Org. Lett. 2017, 19, 4315 .

91. Timmerman, J.; Sims, N.; Wood, J.; J. Am. Chem. Soc. 2019, $141,10082$.

92. Adelin, E.; Servy, C.; Martin, M. T.; Arcile, G.; Iorga, B. I.; Retailleau, P.; Bonfill, M.; Ouazzani, J.; Phytochemistry 2014, 97, 55.

93. Hönig, M.; Carreira, E. M.; Angew. Chem., Int. Ed. 2020, 59, 1192.

94. Ye, Y.; Ozaki, T.; Umemura, M.; Liu, C.; Minami, A.; Oikawa, H.; Org. Biomol. Chem. 2019, 17, 39.

95. Shabani, S.; White, J. M.; Hutton, C. A.; Org. Lett. 2020, 22 , 7730 .

96. Shang, Z. X.; Salim, A. A.; Capon, R. J.; J. Nat. Prod. 2017, $80,1167$.

97. Ogawa, N.; Mamada, S.; Hama, T.; Koshino, H.; Takahashi, S.; J. Nat. Prod. 2020, 83, 2537.

98. Ishida, K.; Murakami, M.; J. Org. Chem. 2000, 65, 5898.

99. Kuranaga, T.; Matsuda, K.; Takaoka, M.; Tachikawa, C.; Sano, A.; Itoh, K.; Enomoto, A.; Fujita, K.; Abe, I.; Wakimoto, T.; ChemBioChem 2020, 21, 3329.

100. Rabe, P.; Rinkel, J.; Dolja, E.; Schmitz, T.; Nubbemeyer, B.; Luu, T. H.; Dickschat, J. S.; Angew. Chem., Int. Ed. 2017, 56, 2776.

101. Chi, H. M.; Cole, C. J. F.; Hu, P.; Taylor, C. A.; Sny, S. A.; Chem. Sci. 2020, 11, 10939.

102. Joyce, L. A.; Nawrat, C. C.; Sherer, E. C.; Biba, M.; Brunskill, A.; Martin, G. E.; Cohen, R. D.; Davies, I. W.; Chem. Sci. 2018, 9, 415 .

103. Inoue, M.; Carson, M. W.; Frontier, A. J.; Danishefsky, S. J.; J. Am. Chem. Soc. 2001, 123, 1878; Hughes, C. C.; Trauner, D.; Tetrahedron 2004, 60, 9675; Ovaska, T. V.; Sullivan, J. A.; 
Ovaska, S. I.; Winegrad, J. E.; Fair, J. D.; Org. Lett. 2009, 11, 2715; Reiter, M.; Torssell, S.; Lee, S.; MacMillan, D. W. C.; Chem. Sci. 2010, 1, 37; Oblak, E. Z.; VanHeyst, M. D.; Li, J.; Wiemer, A. J.; Wright, D. L.; J. Am. Chem. Soc. 2014, 136, 4309 .

104. Batista Jr., J. M.; Blanch, E. W.; Bolzani, V. S.; Nat. Prod. Rep. 2015, 32, 1280; Mándi, A.; Kurtán, T.; Nat. Prod. Rep. 2019 , $36,889$.

105. Batista Jr., J. M.; López, S. N.; Mota, J. S.; Vanzolini, K. L.; Cass, Q. B.; Rinaldo, D.; Vilegas, W.; Bolzani, V. S.; Kato, M. J.; Furlan, M.; Chirality 2009, 21, 799.

106. Li, G.-Y.; Yang, T.; Luo, Y.-G.; Chen, X.-Z.; Fang, D.-M.; Zhang, G.-L.; Org. Lett. 2009, 11, 3714.

107. Ren, J.; Li, G.-Y.; Shen, L.; Zhang, G.-L.; Nafie, L. A.; Zhu, H.-J.; Tetrahedron 2013, 69, 10351.

108. Ikeya, Y.; Taguchi, H.; Yosioka, I.; Kobayashi, H.; Chem. Pharm. Bull. 1979, 27, 1383.

109. He, P.; Wang, X.; Guo, X.; Ji, Y.; Zhou, C.; Shen, S.; Hu, D.; Yang, X.; Luo, D.; Dukor, R.; Zhu, H.; Tetrahedron Lett. 2014, 55, 2965.

110. Cuenca, M. D. R.; Catalan, C. A. N.; Díaz, J. G.; Herz, W.; J. Nat. Prod. 1991, 54, 1162.

111. Pardo-Novoa, J. C.; Arreaga-González, H. M.; Gómez-Hurtado, M. A.; Rodríguez-García, G.; Cerda-García-Rojas, C. M.; Joseph-Nathan, P.; del Río, R. E.; J. Nat. Prod. 2016, 79, 2570 .

112. Liu, X.; Wu, Q.-X.; Shi, Y.-P.; J. Chin. Chem. Soc. 2005, 52, 369.

113. Shi, Y.; Liu, Y.; Li, Y.; Li, L.; Qu, J.; Ma, S.; Yu, S.; Org. Lett. 2014, 16, 5406.

114. Zhao, D.; Li, Z.-Q.; Cao, F.; Liang, M.-M.; Pittman Jr., C. U.; Zhu, H.-J.; Li, L.; Yu, S.-S.; Chirality 2016, $28,612$.

115. Sun, D.-Y.; Han, G.-Y.; Gong, J.-X.; Nay, B.; Li, X.-W.; Guo, Y.-W.; Org. Lett. 2017, 19, 714.

116. Molinski, T. F.; Salib, M. N.; Pearce, A. N.; Copp, B. R.; J. Nat. Prod. 2019, 82, 1183.

117. Guha, K. P.; Mukherjee, B.; Mukherjee, R.; J. Nat. Prod. 1979, 42, 1 .

118. Ren, J.; Zhao, D.; Wu, S.-J.; Wang, J.; Jia, Y.-J.; Li, W.-X.; Zhu, H.-J.; Cao, F.; Li, W.; Pittman, C. U.; He, X.-J.; Tetrahedron 2019, 75, 1194.

119. He, J.; Wijeratne, E. M. K.; Bashyal, B. P.; Zhan, J.; Sliga, C. J.; Liu, M. X.; Pierson, E. E.; Pierson, L. S.; VanEtten, H. D.; Gunatilaka, A. A. L.; J. Nat. Prod. 2004, 67, 1985.

120. Wu, Y.-R.; Yin, G.-P.; Gao, H.-L.; Wang, X.-B.; Yang, M.-H.; Kong, L.-Y.; Fitoterapia 2019, 134, 196.

121. Andolfi, A.; Cimmino, A.; Vurro, M.; Berestetskiy, A.; Troise, C.; Zonno, M. C.; Motta, A.; Evidente, A.; Phytochemistry 2012, 79, 102.

122. Santoro, E.; Vergura, S.; Scafato, P.; Belviso, S.; Masi, M.; Evidente, A.; Superchi, S.; J. Nat. Prod. 2020, 83, 1061.
123. Shan, W. G.; Wang, S. L.; Lang, H. Y.; Chen, S. M.; Ying, Y. M.; Zhan, Z. J.; Helv. Chim. Acta 2015, 98, 552.

124. Lin, S.; Yu, H.; Yang, B.; Li, F.; Chen, X.; Li, H.; Zhang, S.; Wang, J.; Hu, Y.; Hu, Z.; Zhang, Y.; J. Nat. Prod. 2020, 83, 169.

125. Grauso, L.; Teta, R.; Esposito, G.; Menna, M.; Mangoni, A.; Nat. Prod. Rep. 2019, 36, 1005.

126. Pescitelli, G.; Bruhn, T.; Chirality 2016, 28, 466; Merten, C.; Golup, T. P.; Kreienborg, N. M.; J. Org. Chem. 2019, 84, 8797.

127. Raju, R.; Piggott, A. M.; Coute, M. M.; Capon, R. J.; Org. Biomol. Chem. 2010, 8, 4682.

128. Sugiyama, R.; Nishimura, S.; Kakeya, H.; Tetrahedron Lett. 2013, 54, 1531.

129. Rudi, A.; Afanii, R.; Gravalos, L. G.; Aknin, M.; Gaydou, E.; Vacelet, J.; Kashman, Y.; J. Nat. Prod. 2003, 66, 682.

130. Yong, K. W. L.; Barnych, B.; de Voss, J. J.; Vatèle, J.-M.; Garson, M. J.; J. Nat. Prod. 2012, 75, 1792.

131. Collett, L. A.; Davies-Coleman, M. T.; Rivett, D. E. A.; Phytochemistry 1998, 48, 651.

132. Juárez-González, F.; Suárez-Ortiz, G. A.; Fragoso-Serrano, M.; Cerda-García-Rojas, C. M.; Pereda-Miranda, R.; Magn. Reson. Chem. 2014, 53, 203.

133. Wu, J.; Zhang, S.; Bruhn, T.; Xiao, Q.; Ding, H.; Bringmann, G.; Chem.-Eur. J. 2008, 14, 1129.

134. Liu, Y.; Holt, T. A.; Kutateladze, A.; Newhouse, T. R.; Chirality 2020, 32, 515.

135. Ndukwe, I. E.; Wang, X.; Lam, N. Y. S.; Ermanis, K.; Alexander, K. L.; Bertin, M. J.; Martin, G. E.; Muir, G.; Paterson, I.; Britton, R.; Goodman, J. M.; Helfrich, E. J. N.; Piel, J.; Gerwick, W. H.; Williamson, R. T.; Chem. Commun. 2020, 56, 7565.

136. Giorgio, E.; Maddau, L.; Spanu, E.; Evidente, A.; Rosini, C.; J. Org. Chem. 2005, 70, 7.

137. Sarotti, A. M.; J. Org. Chem. 2020, 85, 11566.

138. McDermott, T. S.; Mortlock, A. A.; Heathcock, C. H.; J. Org. Chem. 1996, 61, 700.

139. Liu, H.-B.; Imler, G. H.; Baldridge, K. K.; O’Connor, R. D.; Siegel, J. S.; Deschamps, J. R.; Bewley, C. A.; J. Am. Chem Soc. 2020, 142, 2755.

140. Ankisetty, S.; Amsler, C. D.; McClintock, J. B.; Baker, B. J.; J. Nat. Prod. 2004, 67, 1172.

141. Shilling, A. J.; Witowski, C. G.; Maschek, J. A.; Azhari, A.; Vesely, B. A.; Kyle, D. E.; Amsler, C. D.; McClintock, J. B. Baker, B. J.; J. Nat. Prod. 2020, 83, 1553.

142. Yan, D.; Chen, Q.; Gao, J.; Bai, J.; Liu, B.; Zhang, Y.; Zhang, L.; Zhang, C.; Zou, Y.; Hu, Y.; Org. Lett. 2019, 21, 1475.

143. Breton, R. C.; Reynolds, W. F.; Nat Prod. Rep. 2013, 30, 501.

144. Marcarino, M. O.; Zanardi, M. M.; Cicetti, S.; Sarotti, A. M.; Acc. Chem. Res. 2020, 53, 1922.

145. Della-Felice, F.; Pilli, R. A.; Sarotti, A. M.; J. Braz. Chem. Soc. 2018, 29, 1041. 
146. Nugroho, A. E.; Morita, H.; J. Nat. Med. 2019, 73, 687; http:// cheshirenmr.info/Recommendations.htm, accessed in May 2021.

147. Sarotti, A. M.; Org. Biomol. Chem. 2013, 11, 4847; Zanardi, M. M.; Sarotti, A. M.; J. Org. Chem. 2015, 80, 9371.

148. Smith, S. G.; Goodman, J. M.; J. Org. Chem. 2009, 74, 4597.

149. Smith, S. G.; Goodman, J. M.; J. Am. Chem. Soc. 2010, 132, 12946; Grimblat, N.; Zanardi, M. M.; Sarotti, A. M.; J. Org. Chem. 2015, 80, 12526; Ermanis, K.; Parkes, K. E. B.; Agback, T.; Goodman, J. M.; Org. Biomol. Chem. 2017, 15, 8998; Zanardi, M. M.; Biglione, F. A.; Sortino, M. A.; Sarotti, A. M.; J. Org. Chem. 2018, 83, 11839; Grimblat, N.; Gavín, J. A.; Hernández Daranas, A.; Sarotti, A. M.; Org. Lett. 2019, 21, 4003; Howarth, A.; Ermanis, K.; Goodman, J. M.; Chem. Sci. 2020, 11, 4351 .

150. Kutateladze, A. G.; Reddy, D. S.; J. Org. Chem. 2017, 82, 3368; Kutateladze, A. G.; Mukhina, O. A.; J. Org. Chem. 2015, 80,
5218; Xin, D.; Jones, P.-J.; Gonnella, N. C.; J. Org. Chem. 2018, 83, 5035; Navarro-Vázquez, A.; Gil, R. R.; Blinov, K.; J. Nat. Prod. 2018, 81, 203.

151. Bifulco, G.; Dambruoso, P.; Gomez-Paloma, L.; Riccio, R.; Chem. Rev. 2007, 107, 3744; Grimblat, N.; Sarotti, A. M.; Chem. - Eur. J. 2016, 22, 12246; Casabianca, L. B.; Magn. Reson. Chem. 2020, 58, 61; Costa, F. L. P.; de Albuquerque, A. C. F.; Fiorot, R. G.; Lião, L. M.; Martorano, L. H.; Mota, G. V. S.; Valverde, A. L.; Carneiro, J. W. M.; dos Santos Jr., F. M.; Org. Chem. Front. 2021, 8, 2019.

152. Taniguchi, T.; Monde, K.; J. Am. Chem. Soc. 2012, 134, 3695.

153. Passareli, F.; Batista, A. N. L.; Cavalheiro, A. J.; Herrebout, W. A.; Batista Jr., J. M.; Phys. Chem. Chem. Phys. 2016, 18, 30903.

Submitted: February 22, 2021

Published online: May 27, 2021 